\title{
TAXONOMY, GEOGRAPHIC DISTRIBUTION, CONSERVATION AND SPECIES BOUNDARIES IN CALYDOREA AZUREA GROUP (IRIDACEAE: TIGRIDIEAE) ${ }^{1}$
}

\author{
LEONARDO PAZ DEBLE ${ }^{2}$ ANABELA SILVEIRA DE OLIVEIRA DEBLE ${ }^{3}$ FABIANO DA SILVA \\ ALVES $^{4}$ LUIZ FELIPE GARCIA ${ }^{5}$ SABRINA ARIANE OVIEDO REFIEL LOPES ${ }^{6}$
}

\begin{abstract}
For this study were performed observations in populations of Calydorea azurea Klatt and allied taxa, along of the ecosystems of the Río de La Plata Grasslands, geographic extent where occur this group. For the complementation of the data were examined collections deposited in the principal herbaria of southern Brazil, Uruguay and Argentina, and were analyzed image of types and others collections available. All studied species were photographed and its populations geo-referenced. It are recognized six species: C. alba Roitman \& Castillo, C. azurea, C. charruana Deble, C. luteola (Klatt) Baker, C. minima Roitman \& Castillo and C. riograndensis Deble. C. azurea is cited for Brazil, C. charruana is added to Argentinian flora, C. luteola has its taxonomic delimitation established, and its occurrence is extended up to the northern Uruguay. The geographic distribution of $C$. riograndensis is reestablished, in view of three collections mentioned in the protologue are identified as belonging at others species. All species studied are described, illustrated through of photos, being presented data about geographic distribution, ecology and conservation.
\end{abstract}

Keywords: Basin of Rio de La Plata; Bulbous; Ecology; Grasslands Ecosystems; Pampa Biome.

\section{RESUMO}

[Taxonomia, distribuição geográfica, conservação e limites entre as espécies no grupo de Calydorea azurea (Iridaceae: Tigridieae)].

Para este estudo foram feitas observações na natureza de populações de Calydorea azurea Klatt e táxons afins, ao longo dos ecossistemas campestres do entorno da Bacia do Prata, espaço geográfico onde se distribui o grupo em estudo. Para a complementação dos dados, foram examinadas exsicatas colecionadas nos principais herbários do sul do Brasil, Uruguai e Argentina e também imagem de tipos e outras coleções disponíveis. Todas as espécies foram fotografadas, tendo suas populações georreferenciadas. São reconhecidas seis espécies para o complexo de Calydorea azurea: C. alba Roitman \& Castillo, C. azurea, C. charruana Deble, C. luteola (Klatt) Baker, C. minima Roitman \& Castillo e C. riograndensis Deble. C. azurea é adicionada a flora do Brasil, $C$. charruana é acrescentada a flora da Argentina, $C$. luteola tem sua delimitação taxonômica definida, tendo sua ocorrência ampliada até o norte do Uruguai e C. riograndensis tem sua distribuição geográfica reestabelecida, tendo em vista que três coleções atribuídas a essa espécie são identificadas como pertencentes a outras espécies. Todas as espécies são descritas e ilustradas através de fotos, sendo apresentadas informações sobre distribuição geográfica, ecologia e conservação.

Palavras chave: Bioma Pampa; Bulbosas; Ecologia; Ecossistemas Campestres; Bacia do Rio da Prata.

1 Recebido em 10-08-2018 e aceito para publicação em 10-10-2018. Núcleo de Estudos Botânicos Balduino Rambo, Departamento de Ciências Florestais, UFSM. Santa Maria, RS, Brasil.

2 Biólogo, Universidade Federal do Pampa, Dom Pedrito, RS. deble.biol@gmail.com

3 Curso de Ciências Biológicas, Universidade da Região da Campanha, Bagé, RS.

4 Curso de Ciências Biológicas, Universidade da Região da Campanha, Alegrete, RS.

5 Curso de Ciências da Natureza, Universidade Federal do Pampa, Dom Pedrito, RS.

6 Zootecnista, Universidade Federal do Pampa, Dom Pedrito, RS. sabrinarefiel@gmail.com

\section{INTRODUCTION}

Calydorea Herbert (1843, p. 85) is a genus of small seasonal perennials plants centered in temperate South America (Roitman \& Castillo, 2005, 2007; Deble, 2011; Deble et al., 2013, 2016), and according with the World Check List of Iridaceae (WCI) includes 21 species (Barker, 2018). The genus can be morphologically characterized by its deceptively simple flowers, recognized by the absence of lipid trichomes, 
free stamens, curved or twisted anthers at dehiscence, and filiform style branches that often extend between the stamens, and ending in one obtuse or shortly emarginated stigmatic area (Ravenna, 2003, 2005, 2009; Goldblatt \& Manning, 2008; Chauveau et al., 2012).

The here designated "Calydorea azurea group" includes species distributed on the grasslands of Río de la Plata (RPG), mainly in northern Campos of Brazil (Pampa Biome, sensu IBGE, 2004), Uruguay and Argentina, and the Mesopotamic Pampa, in Entre Ríos, northeast Argentina (the delimitation of the RPG following Soriano et al., 1992; Olson et al., 2001; Azpiroz et al., 2012). All taxa of the group are very closely related and the boundaries among them is difficult to establish. However, the mentioned group have distinctive attributes, resulting easy the segregation of others species of Calydorea (Ravenna, 2005). The mainly features are the following: (1) two-flowered spathes; (2) perigone with outer and inner tepals similar in shape and color; (3) tepals without trichomes; (4) stamens with narrow linear filaments, at the base abruptly thickened, and anthers twisted at dehiscence; (5) oblong ovary, and the style not arranged with the stamens, with style branches not grooved, and stigmatic trichomes forming a crown at top (see Roitman \& Castillo, 2005, 2007; Ravenna, 2005; Deble, 2011; Deble et al., 2013).

In more one contribution for the knowledge of the genus Calydorea, we discuss the taxonomy, geographic distribution, conservation, and species boundaries in Calydorea azurea group based mainly in observation of populations in the wild and exsiccates. All species studied are described, and comments about ecological data, taxonomic affinities are presented; moreover, maps of geographic distribution, photos, and a key to distinguish the species are also supplied.

\section{MATERIALS AND METHODS}

To conduct this study, collections from wild populations of Calydorea were performed in northeastern Argentina, southern Brazil, and Uruguay, between October 2010 and December 2017. Additionally were evaluated specimens of Calydorea (including digital images) deposited in the following herbaria: B, CORD, CTES, FCQ, FLOR, G, HAS, HBR, ICN, K, LP, MVHM, MVM, MVFA, MVJB, NY, P, PACA, PY, R, RB, SGO, S, SI, SP, and US (herbaria acronym follows Thiers, 2018). Moreover, species of Calydorea are also cultivated, and data about phenology and others aspects were observed. The morphological data mentioned in the key is based on the examined material (including live specimens), and the terminology follows Goldblatt \& Manning (2008), and Beentje (2010). The data for conservation are based in the criteria of IUCN (2014).

\section{RESULTS AND DISCUSSIONS}

With the data obtained are recognized six species as belonging to $C$. azurea group: $C$. alba Roitman \& Castillo (2005, p. 311), C. azurea Klatt (1882, p. 387), C. charruana Deble in Deble et al. (2013, p. 2), C. luteola (Klatt 1862, p. 563) Baker (1876, p. 188), C. minima Roitman \& A. Castillo ex Deble (2011, p. 39), and $C$. riograndensis Deble (2011, p. 35). The species are presented in alphabetical sequence, containing the following data: description, material examined, geographic distribution and habitat, ecology, size of populations and natural history, conservation, and taxonomic relationships. 
Key to distinguish the species of Calydorea azurea group

1a. Style columnar; style branches fused ... Calydorea charruana

1b. Style not columnar; style branches free for $2 \mathrm{~mm}$ or more

2a.Perigone nearly campanulate. Tepals slight fused towards the base. Stamens with anthers up to $3 \mathrm{~mm}$ long, filaments up to $1.5 \mathrm{~mm}$ long Calydorea minima

2b.Perigone disciform. Tepals spreading, free towards the base. Stamens with anthers $4 \mathrm{~mm}$ long or more, filaments $2 \mathrm{~mm}$ long or more ... 3

3a. Style branches subulate, ending in an obtuse stigmatic area .................. Calydorea alba 3b. Style branches not subulate, ending in a truncate or emarginated stigmatic area ........... 4 4a. Plants robust, $20-40 \mathrm{~cm}$ high above the soil, growing in sedimentary areas near to Uruguay River. Perigone 44-56 mm in diameter Calydorea azurea

4b.Plants more delicate, $10-25 \mathrm{~cm}$ high above the soil, growing in grasslands and stony grasslands. Perigone $18-35 \mathrm{~mm}$ in diameter

5a.Perigone 24-35 mm in diameter. Tepals 5-9 mm wide. Seeds ca. 1.6-2 mm long, epidermis minutely foveolate Calydorea luteola

5b.Perigone 18-22 $\mathrm{mm}$ in diameter. Tepals 3-6 mm wide. Seeds ca. 0.9-1.5 mm long, epidermis smooth, with grooves

Calydorea riograndensis

1. Calydorea alba Roitman \& A. Castillo, Bol. Soc. Argent. Botánica 40 (3-4): 311. 2005. Typus: URUGUAY. Artigas depto: "wet grasslands" 9 October 2003, G. Roitman, G. M. Tourn \& M. Panziera s.n. (holotype: BAA 25500!). (Figs. 1A, 2)

Description: Plant up to $20-25 \mathrm{~cm}$ high above the soil; underground stems $3-5 \mathrm{~cm}$ long. Bulb subglobose, 20-25 × 20-25 mm, prolonged in a collar, up to $5 \mathrm{~cm}$ long, cataphylls darkbrown, apex acute. Leaves at anthesis, 1-4, green, plicate, narrowly linear, $10-16 \times 0.1-0.2 \mathrm{~cm}$. Flowering stems $14-21 \mathrm{~cm}$, branching only in flowering spathes. Cauline leaf linear-ensiform, $2.5-4 \times 0.5-0.2 \mathrm{~cm}$, base involving the stem. Spathes 1-2, green, herbaceous, bivalved, twoflowered, 21-30 × 2-3 mm, peduncles 1.8-3.1 $\mathrm{cm}$ long. Outer valve 12-17 $\mathrm{mm}$ long, the inner 19-28 mm long, convolute, both with membranous edges. Pedicel filiform, up to 30 $\mathrm{mm}$ long. Flower predominately white, radially symmetrical, $25-40 \mathrm{~mm}$ in diameter. Tepals whorls sharply similar in shape and color, spreading, proximally yellow, after with blue or dark-blue stripes; outer tepals oblong or oblanceolate, $16-20 \times 5-8 \mathrm{~mm}$, apex slightly obtuse to rounded; inner tepals oblong or oblanceolate, $14-19 \times 4.5-7.5 \mathrm{~mm}$, at apex slightly acute to obtuse. Filaments free, yellowish, linear and wider at base, 2-3 mm long; anthers linear, twisted at dehiscence, 4-5 mm long; pollen yellow. Ovary obovate, $4-5 \times$ 1.5-2 mm. Style yellowish, 8-10 mm long; style branches filiform, at topnarrowed, 3-5 mm long; stigma obtuse, yellow or violet. Capsule oblong, 7-10 $\times 4-5 \mathrm{~mm}$. Seeds oblong to obconical, ca. $2 \mathrm{~mm}$ long, angled, reddish-brown, epidermis minutely foveolate.

Material examined: URUGUAY. Artigas: "in wet grasslands", 9 October 2003, G. Roitman, G.M. Tourn \& M. Panziera s.n. (BAB 25005 !, type of C. alba). Arroyo Yacuy, ruta 3, 4 November 1963, Arrilaga et al.1656 (MVFA!). Mazzoler, "no campo, flores pálidas, ca. $3.5 \mathrm{~cm}$ diam., 15 November 2014, L. P. Deble, A. S. Oliveira-Deble \& F. S. Alves 15216 (SI!). BRAZIL. Rio Grande do Sul: Quarai, Localidade do Jarau, "campo raso desenvolvido sobre rocha vulcânica", 9 November 2011, L.P. Deble \& A.S. de Oliveira-Deble 11831 (PACA!). Uruguaiana: BR 290, km 645, 3000'43"'S, 56 21'48'W, L. Eggers et al. 871 (ICN!); BR 290, 2958'33.1''S, 56³2' 55.3”'W, 7 November 2007, A. A. Schneider 1560 (ICN!).

Geographic distribution and habitat: Calydorea alba occurs in southwest Rio Gran- 
de do Sul State, Brazil, and Artigas Department, northwest Uruguay, in an extent of occurrence estimated smaller than $35,000 \mathrm{~km}^{2}$, and an area of occupancy less than $5,000 \mathrm{~km}^{2}$. The specimens grow on stony grasslands or grasslands with shallow soils or deep, developed on volcanic rocks, often wet, and with few capacity of drainage.

Ecology, size of populations and natural history: Calydorea alba is one of the most characteristic species of the grasslands developed on volcanic rocks in north Uruguay and southwest Rio Grande do Sul, being abundant in several places. The specimens occur mainly in the sources of Quaraí River and in the middle course of this same river and its tributaries, along the border between Brazil and Uruguay. The populations occur exclusively in native and well-preserved grasslands, and are often composed by many individuals. Specimens flowering fullness between September-November, producing several fruits and seeds, and can flourish sporadically in others months, mainly after the rain. The flowers open only few hours in one day, in the early morning and wither at midday. During our field activities was observed species of hoverfly (Syrphidae) hovering or nectaring at flowers. Others species of Iridaceae registered in the same environments are Calydorea minuana Deble \& F.S. Alves, Cypella discolor Ravenna, C. fucata Ravenna, C. luteogibbosa Deble, Herbertia amoena Grisebach, H. darwinii Roitman \& A. Castillo, H. lahue (Molina) Goldblatt, H. quareimana Ravenna, Onira unguiculata (Baker) Ravenna and several species of Sysirinchium.

Conservation: The geographic distribution of Calydorea alba is smaller than $35,000 \mathrm{~km}^{2}$, and the area of occupancy is smaller than 5,000 $\mathrm{km}^{2}$. The populations are fragmented, but often containing many individuals. The extent of occurrence of $C$. alba has been intensely used by man, mainly for cattle, and more recently also for silviculture and agriculture. The increase of silviculture and agriculture result in direct threat to species, since the populations of $C$. alba spread only in natural and well-preserved grasslands. According to the IUCN Red List assessment protocol (IUCN 2014) the species can be assigned to the Vulnerable category (VU, B1, B2b(iii), c(ii)), due to the extent of occurrence, area of occupancy, specific habitat, and anthropic threats observed.

Taxonomic relationships: Calydorea alba is closely related to C. luteola, and in some populations is difficult distinguish both species. Despite this similarity we prefer to maintain $C$. $a l b a$ as segregated because the flowers of $C$. alba are bigger and the tepals are oblong or oblanceolate (vs. often broadly elliptic), and the style and style branches are more slender, ending in an obtuse stigmatic portion.

2. Calydorea azurea Klatt, Abh. Naturf. Ges. Halle 15: 387 (1882). Typus: ARGENTINA. Entre Rios Prov.: Concepción del Uruguay "in campis baj." April 1875, P.G. Lorentz 135 (holotype B, B0247606 photo!, isotype CORD!). (Figs. 1B, 2)

Description: Plant up to $20-40 \mathrm{~cm}$ high above the soil; underground stems 4-7 cm long. Bulb subglobose, 20-25 × 20-25 mm, prolonged in a collar, up to $5 \mathrm{~cm}$ long, cataphylls darkbrown, apex acute. Leaves at anthesis 2-4, green, plicate, narrowly linear, $14-25 \times 0.2-0.5 \mathrm{~cm}$. Flowering stems $18-35 \mathrm{~cm}$, branching only in flowering spathes. Cauline leaf linear-ensiform, $5-7.5 \times 0.1-0.2 \mathrm{~cm}$, base involving the stem. Spathes 1-4 per branch, green, herbaceous, bivalved, two-flowered, $25-40 \times 2-3 \mathrm{~mm}$, peduncles $2.5-4.5 \mathrm{~cm}$ long. Outer valve $16-22$ $\mathrm{mm}$ long, the inner 24-39 mm long, convolute, both with membranous edges. Pedicel filiform, up to $40 \mathrm{~mm}$ long. Flower pallid blue or skyblue, radially symmetrical, 44-56 $\mathrm{mm}$ in diameter. Tepals whorls sharply similar in shape and color, proximally yellowish, after with blue or dark-blue stripes, spreading; outer tepals oblong or obovate-oblong, $21-30 \times 8-11 \mathrm{~mm}$, apex rounded; inner tepals oblong, elliptic or obovate, $18-28 \times 8-11 \mathrm{~mm}$, at apex rounded to obtuse. Filaments free, white-cream, filiform 
and wider at base, 2-3 mm long; anthers linear, twisted at dehiscence, 5-6 mm long; pollen yellow. Ovary obovate, $4-5 \times 1.5-2 \mathrm{~mm}$. Style yellowish, 8-10 $\mathrm{mm}$ long; style branches filiform, 2.5-4 mm long; stigma obtuse to truncate, bluish. Capsule oblong, 9-11 ×4-5 mm. Seeds oblong to obconical, ca. $2 \mathrm{~mm}$ long, angled, reddish-brown, epidermis minutely foveolate.

Material Examined: ARGENTINA. Corrientes: Curuzú Cuatiá, "12 km acesso N de Curuzú Cutiá” 22 March 1983, C. Cristóbal et al. 1983 (CTES!); "10 km E de Curuzú Cuatiá" 23 November 1990, T. M. Pedersen 15622 (CTES!). Entre Ríos: Concepción del Uruguay, April 1875, P.G. Lorentz 135 (B, photo! CORD!, type of C. azurea). Dep. Federación, Chajarí, E. G. Nicora 6178 (SI!); ruta Nac- 14, rotonda entrada a Chajarí, Giussani 436 (SI); Chajarí a Villa Rosario, N. Troncoso 3855 (SI!).Dep. Gualeguay, aldea Asunción, Hurrell et al. 5081 (SI!). Dep. Gualeguaychú, Pto. Constanza a Gualeguaychú, E. G. Nicora 6502 (SI). BRAZIL. Rio Grande do Sul: Barra do Quaraí, Parque do Espinilho, 17 November 1984, M. Sobral 3394 (ICN!). URUGUAY. Paysandú: Est. El Mirador, 9 October 1961, Del Puerto 305 (MVFA!); ruta 26, ca. Lorenzo Geyres, $32^{\circ} 03^{\prime} 23.2^{\prime \prime} \mathrm{S}$, and $57^{\circ} 42^{\prime} 26.4^{\prime \prime} \mathrm{W}, 24$ October 2014, L.P. Deble \& A.S. de Oliveira-Deble 15689 (MVFA! SI!). Salto: Paso Isleta, al camino a las Termas de Arapey, 20 October 1961, Millot 534 (MVFA!).

Geographic distribution and Habitat: Calydorea azurea occurs in a narrow strip in sedimentary areas and sandy, on alluvial plain of the Uruguay River and tributaries, in eastern and northeastern Entre Rios, and southern Corrientes, Argentina, western and northwestern Uruguay, in the departments of Artigas, Paysandú, Salto and Río Negro and westernmost RS state, Brazil (Barra do Quaraí municipality). The extent of occurrence estimated is smaller than $20,000 \mathrm{~km}^{2}$, and the area of occupancy less than $2,000 \mathrm{~km}^{2}$. Calydorea azurea has its geographic range increased up to RS state, where one population with untypical white flowers was registered.

Ecology, size of populations and natural history: The specimens occur on alluvial plain, and sandy grasslands. The specimens flowering fullness between October-November, and February-March, producing a great number of fruits and seeds. The flowers open only few hours in one day, in the early morning and wither at midday or early afternoon. The populations are fragmented but usually are composed by many individuals. Others species of Iridaceae registered in the same environments are Calydorea charruana Deble, Cypella armosa Ravenna, C. fucata Ravenna, Herbertia amoena Grisebach, H. lahue (Molina) Goldblatt, and species of Sysirinchium.

Conservation: The geographic distribution of Calydorea azurea is smaller than $20,000 \mathrm{~km}^{2}$, and the area of occupancy is smaller than 2,000 $\mathrm{km}^{2}$. The populations are fragmented, but often containing many individuals. The extent of occurrence of $C$. azurea has been intensely used by man, mainly for silviculture and agriculture. The increase of silviculture and agriculture result in direct threat to this species, since the populations of $C$. azurea spread only in natural environments. According to the IUCN Red List assessment protocol (IUCN 2014) the species can be assigned to the Vulnerable category (VU, B1, B2b(iii), c(ii)), due to the extent of occurrence, area of occupancy, specific habitat, and anthropic threats observed.

Taxonomic relationships: Calydorea azurea resembles $C$. luteola, but can be distinguished by its robust habit and bigger tepals, having different shape. This species is also similar to C. alba, but the flowers are bigger and displays perigone pallid blue or sky-blue, and the style has more thickened style branches, ending in a truncate stigmatic portion.

3. Calydorea charruana Deble, Balduinia 40: 2. 2013. Typus: BRAZIL. Rio Grande do Sul State: Dom Pedrito " $40 \mathrm{~km}$ southwest of the city, on grasslands, flowers violet-blue fl., 
fr.," 17 October 2011, L.P. Deble \& A.S. de Oliveira-Deble 10801 (holotype: PACA!). (Figs. 1C, 2)

Description: Plant up to $15-35 \mathrm{~cm}$ high above the soil; underground stems $4-8 \mathrm{~cm}$ long. Bulb depressed globose, 20-30 $\times 20-30 \mathrm{~mm}$, prolonged in a collar, up to $5 \mathrm{~cm}$ long, cataphylls dark-brown, apex acute. Leaves at anthesis 4-8, green, plicate, linear, $6-15 \times 0.2-0.5 \mathrm{~cm}$. Flowering stems $11-31 \mathrm{~cm}$, often 2-furcated at apex. Cauline leaf linear-ensiform, 3-4 × 0.2$0.3 \mathrm{~cm}$, base involving the stem. Spathes $2-3$ per branch, green, herbaceous, bivalved, twoflowered, $26-38 \times 3-4 \mathrm{~mm}$, peduncles $2-4 \mathrm{~cm}$ long. Outer valve $18-24 \mathrm{~mm}$ long, the inner $24-$ $34 \mathrm{~mm}$ long, convolute, both with membranous edges. Pedicel filiform, up to $40 \mathrm{~mm}$ long. Flower sky-blue or violet-blue, radially symmetrical, 30-52 $\mathrm{mm}$ in diameter, at base yellow, surrounded by a blue or dark violet macula. Tepals whorls sharply similar in shape and color, spreading, proximally yellow, after with a dark-blue macula; outer tepals oblong or obovate-oblong, $17-26 \times 8-11 \mathrm{~mm}$, apex slightly acute to rounded; inner tepals oblong or elliptic, $16-24 \times 8-10 \mathrm{~mm}$, at apex slightly acute to obtuse. Filaments free, yellowish, filiform and wider at base, 2.5-3 mm long; anthers linear, twisted at dehiscence, 4-5 mm long; pollen yellow. Ovary obovate, $4-6 \times 1.5-2 \mathrm{~mm}$. Style yellowish, 8-10 $\mathrm{mm}$ long; style branches connate; stigma truncate, bluish, nearly reniform in shape. Capsule oblong, 10-12 × 6-6.5 mm. Seeds oblong to obconical, ca. $2 \mathrm{~mm}$ long, angled, reddish-brown, epidermis minutely foveolate.

Material examined: ARGENTINA. Entre Ríos: Concordia, ruta 14 , desvio al $\mathrm{N}$ de $\mathrm{A}^{\circ}$ Rabón, 5 December 1982, N. Troncoso, $N$. Bacigalupo \& R. Guaglianone 3566 (SI!). Ubajay, em campo, flores azul-pálido ca. 3-3.5 cm diam." 21 December 2015, L. P. Deble \& F. S. Alves 15712 (SI!). BRAZIL. Rio Grande do Sul: Aceguá, on grasslands, flowers blue-lilac, 7 November 2011, L.P. Deble et al. 13584 (PACA!). Dom Pedrito, $40 \mathrm{~km}$ southwest of the city, on grasslands, flowers violet-blue, 17 October 2011, fl., fr., L.P. Deble \& A.S. de Oliveira-Deble 10801 (PACA!, type of $C$. charruana); Ponche Verde locality, 4 October 2017, L. P. Deble, S. R. Lopes \& C. Dias de Dias 16944 (PACA!). URUGUAY. Without Department: "Montevideo", Cerro Rincon, November 1874, M. Fruchard s.n. (P02066913!). Paysandú: ruta 26, 24 October 2015, L. P. Deble \& A. S. de Oliveira-Deble 15703 (MVFA!). Soriano: Vera, 18 November 1898, M. B. Berro 2264 (MVFA!). Salto: ruta 31, 26 October 2015, L. P. Deble \& A. S. de Oliveira-Deble 15703 (MVFA!). Tacuarembó: ruta 26, 24 October 2015, L. P. Deble \& A. S. de Oliveira-Deble 15702 (MVFA! PACA!).

Geographic distribution and Habitat: Calydorea charruana occurs in southern RS, northeastern, central and western Uruguay, and northeastern Entre Ríos Province, Argentina, in an extent of occurrence of ca. $75,000 \mathrm{~km}^{2}$, and an area of occupancy more than $5,000 \mathrm{~km}^{2}$. The specimens grow on grasslands with deep soils, developed often on sedimentary areas, and more rarely, on grasslands developed on volcanic rocks. This species is presently added to Argentine, being found in this country on sedimentary areas near to Uruguay River.

Ecology, size of populations and natural history: The populations occur exclusively in native and well-preserved grasslands, and are composed by few individuals. Specimens flourish fullness between October-November, producing a great number of fruits and seeds, and can flourish sporadically in others months, mainly after the rain. The flowers open only few hours in one day, in the early morning and wither at midday. In the grasslands of Cerro Largo Department, Uruguay, and Aceguá Municipality, southern Rio Grande do Sul State, Calydorea charruana is sympatric with the following Iridaceae: Calydorea nuda (Herbert) Baker, Cypella herbertii (Herbert) Herbert, Gelasine uruguaiensis Ravenna, Herbertia lahue (Molina) Goldblatt, H. pulchella Sweet, Onira unguiculata (Baker) Ravenna and several 
species of Sysirinchium. In the occidental portion of the geographic distribution, Calydorea charruana grows also with C. azurea Klatt.

Conservation: Deble et al. (2013, p. 2) following the criteria of IUCN Red List assessment protocol placed $C$. charruana as Vulnerable category (VU). However, with new data and a careful analyses of populations is prudent to recognize C. charruana as Near Threatened (NT); however, if the suppression of the native grasslands increase in the next years, this species should be placed again in a threat category.

Taxonomic relationships: Calydorea charruana is easily recognized by its style with fused style-branches, forming a stigmatic portion well developed and nearly reniform in shape. Despite its morphologic peculiarity, this species is close related to $C$. azurea, but often displays smaller flowers and more thickened spathes.

4.Calydorea luteola (Klatt) Baker, J. Bot. 14: 188. 1876. = Boterbe luteola Klatt, Linnaea 31: 563.1862. = Roterbe luteola Klatt in C.F.P.von Martius \& auct. suc. (eds.), Fl. Bras. 3(1): 544. 1871. [orth. var.] Typus: BRAZIL. Rio Grande do Sul State: "Brasilae meridionalis, (...) ebenda über S. Gabriel in den nördlichsten Teil von Uruguay zurück nach Alegrete" December 1825/May 1826, F. Sellow 3598 (holotype: B, B100005446 photo! isotype: K, K000363162 photo!). (Figs. 1D, 2)

Description: Plant up to $15-25 \mathrm{~cm}$ high above the soil; underground stems $3-5 \mathrm{~cm}$ long. Bulb depressed globose, 20-30 $\times 20-30 \mathrm{~mm}$, prolonged in a collar, up to $4 \mathrm{~cm}$ long, cataphylls dark-brown, apex acute. Leaves at anthesis 2-3, green, plicate, linear, $6-15 \times 0.2-0.3 \mathrm{~cm}$. Flowering stems $10-21 \mathrm{~cm}$, often 2 -furcated at apex. Cauline leaf linear-ensiform, 2.5-3.5 $\times 0.2$ $0.3 \mathrm{~cm}$, base involving the stem. Spathes 2-3 per branch, green, herbaceous, bivalved, twoflowered, 20-28 $\times 2-3 \mathrm{~mm}$, peduncles $1.5-4 \mathrm{~cm}$ long. Outer valve $14-20 \mathrm{~mm}$ long, the inner 20-
$28 \mathrm{~mm}$ long, convolute, both with membranous edges. Pedicel filiform, up to $35 \mathrm{~mm}$ long. Flower bluish-white or light-blue, radially symmetrical, 24-35 $\mathrm{mm}$ in diameter, at base yellow, surrounded by blue or dark-blue stripes or stains. Tepals whorls sharply similar in shape and color, spreading, proximally yellow, after with blue stripes; outer tepals elliptic to broadly elliptic, $12-16 \times 5-9 \mathrm{~mm}$, apex slightly acute to obtuse; inner tepals elliptic to broadly elliptic, $11-15 \times 5-8 \mathrm{~mm}$, at apex slightly acute to obtuse. Filaments free, yellowish, linear and wider at base, 2-3 mm long; anthers linear, twisted at dehiscence, 4-5 mm long; pollen yellow. Ovary obovate, 4-5 × 1.5-2 mm. Style yellowish or white, 7-10 mm long; style branches $2.5-3.5 \mathrm{~mm}$; stigma shortly emarginated, bluish. Capsule oblong, 9-10 × 4.5-5 mm. Seeds oblong to obconical, ca. 1.6-2 mm long, angled, reddishbrown, epidermis minutely foveolate.

Material examined: BRAZIL. Rio Grande do Sul: "Brasilae meridionalis, (...) ebenda über S. Gabriel in den nördlichsten Teil von Uruguay zurück nach Alegrete" December 1825/ May 1826, F. Sellow 3598 (B, B100005446 photo! K, K000363162 photo!). Alegrete, "Reserva Biológica do Ibirapuitã, acesso pela estrada municipal do Catimbau-ALE 012, no campo, próximo ao Cerro do Catimbau, abundante", $29^{\circ} 57^{\prime} 13^{\prime \prime} \mathrm{S}$ and $55^{\circ} 39^{\prime} 14^{\prime \prime} \mathrm{W}, 12$ November 2011, L.P. Deble \& A.S. de OliveiraDeble 13038 (PACA!); Durasnal, "among volcanic rocks and grasslands", $29^{\circ} 55^{\prime} 01.77$ "S55³0'15.84'W, 4 November 2013, L.P. Deble \& A.S. de Oliveira-Deble 14851 (SI!). Manoel Viana, estrada secundária entre Manoel Viana e São Francisco de Assis, 2945'39"S, 55'21'14"W, 10 November 2013, E. M. StiehlAlves et al. 101 (ICN!). Santana do Livramento: Cerros Verdes, no campo, flores lilases, 14 February 2011, fl. , L. P. Deble, A. S. de Oliveira-Deble, J.N.C. Marchiori, F. Alves \& R. Matielo 12.483 (CTES!). URUGUAY. Rivera: Moirones, cercanias de Yaguary, en campo rocoso, 8 November 2011, L. P. Deble \& A.S. Oliveira-Deble 10899 (MVFA!). 
Geographic distribution and habitat: Calydorea luteola occurs in southwest Rio Grande do Sul State, Brazil, and north Uruguai, Rivera Department, in an extent of occurrence estimated smaller than $20,000 \mathrm{~km}^{2}$, and an area of occupancy less than $1,000 \mathrm{~km}^{2}$. The specimens grow on stony grasslands or grasslands with shallow soils to deep.

Ecology, size of populations and natural history: Calydorea luteola is a rare species, growing on grasslands in the lower parts and around the range of the Mountains of Caverá, in the municipalities of Santana do Livramento, Rosário do Sul and Alegrete, in southwest RS and in north of Rivera, Uruguay. The populations occur exclusively in native and well-preserved grasslands, and are composed by many individuals. Specimens flourish fullness between September-November, producing several fruits and seeds, and can bloom sporadically in others months, mainly after the rain. The flowers open only few hours in one day, in the middle morning and wither at midday. During our field activities was observed species of bee (Meliponinae) and hoverfly (Syrphidae) hovering or nectaring at flowers. This species is sympatric with others Iridaceae, e.g., Calydorea approximata Foster, Cypella discolor Ravenna, C. fucata Ravenna, C. pusilla (Link \& Otto) Jackson, Herbertia amoena Grisebach, H. lahue (Molina) Goldblatt and several species of Sisyrinchium.

Conservation: The geographic distribution of Calydorea luteola is smaller than $20,000 \mathrm{~km}^{2}$, and the area of occupancy is smaller than 2,000 $\mathrm{km}^{2}$. The populations are fragmented, but often containing many individuals. The extent of occurrence of $C$. luteola has been intensely used by man, mainly for cattle, and more recently also for agriculture and Silviculture. These environments are suffering with the invasion of Eragrostis plana Ness, an exotic plant from Africa, which hast reduced the areas of native grasslands. The increase of agriculture and the invasion of Eragrostis plana result in direct threat to this species, since the populations of
C. luteola spread only in natural and wellpreserved grasslands. According to the IUCN Red List assessment protocol (IUCN 2014) the species can be assigned to the Vulnerable category (VU, B1, B2b (i, ii, iii), c(ii)), due to the extent of occurrence, area of occupancy, specific habitat, and anthropic threats observed.

Taxonomic relationships: Calydorea luteola is closely related to $C$. alba and $C$. riograndensis; however, can be segregated from C. alba by its elliptic or broadly elliptic outer and inner tepals ( $v s$. oblong or oblanceolate) and shortly emarginated stigma (vs. obtuse); moreover, the flowers are usually smaller and have different color. C. luteola differs from $C$. riograndensis mainly by its robust habit, wider tepals, usually bigger flowers and bigger seeds with epidermis minutely foveolate.

Resurrection and identity of $\boldsymbol{C}$. luteola: Klatt (1862) described Boterbe luteola as having "perigonii laciniis subaequalibus, luteolis, oblong-spathulatis, patentissimis, filamentis liberis, erectis, basi perigonii insertis; stylo elongato, medio tripartito, stigmatibus emarginatis, capsula oblonga". The same author, in his monograph for the "Flora Brasiliensis" shows key and description for the species of Boterbe (renamed as Roterbe), including diagnosis and drawing of B. luteola (Klatt, 1871). Later, Baker $(1876,1877)$, placed this species under Calydorea, and mentioned in the diagnosis "luteae, styli ramis elongatis". Subsequently, Baker (1892) in his "Handbook of Irideae" expand the description, mentioning “(...) Perianth-segments equal, oblanceolate, yellow, $1 / 2$ in long. Anthers as long as the filaments. Style-branches subulate, emarginate at the tip". The alleged yellow perigone, mentioned both in the works of Klatt (1862, 1871) and Baker (1876, 1877, 1892) contributed for the recognition of $C$. luteola as a uncertain name during more than 100 years, since yellow flowers are not reported to the genus Calydorea. This species is not cited in the works of Ravenna, Roitman \& Castillo and Deble, and is treated as doubtful in the "Catálogo de las Plantas 
Vasculares del Conosur" (Instituto Darwinion, 2018). Nevertheless, Deble et al. (2016) mentioned $C$. luteola as native in the Grasslands of the Río de La Plata. After, C. luteola is also listed as a valid species in the Brazilian Flora Online (Eggers, 2018).

As it is possible to verify, this species has again come to appear as a valid name, even without having a proper explanation about this taxonomic decision. We analyzed the type and following Urban (1893), the collection Sellow 3598 was performed "ebenda über S. Gabriel in den nördlichsten Teil von Uruguay zurück nach Alegrete" between December 1825 and May 1826. During trips in the possible places where was performed the collection Sellow 3598 was found only two species of Calydorea, one of them is $C$. approximata easily recognized by its sessile spathes and the other having size and general aspect entirely similar with the type of C. luteola. Furthermore, the perigone and the morphological characteristics of style-branches, stigmatic area, and stamens of this last species are very similar with the description and illustration of $C$. luteola (see Klatt, 1862; 1871). However, this species displays light blue flowers and not yellow, as mentioned for $C$. luteola, but as the description performed by Klatt was based on dry material, it is evident that it was a misinterpretation resulting from the drying process of the tepals, which was also reproduced by Baker in his works.

5. Calydorea minima Roitman \& A. Castillo ex Deble, Bonplandia (Corrientes) 20: 39. 2011. Typus: ARGENTINA. Corrientes Prov.: San Tomé, Garruchos "cercanías de Garruchos", 10 October 2006, G. Roitman s.n. (BAA 25701!). (Figs. 1E, 2)

Description: Plant up to $8-15 \mathrm{~cm}$ high above the soil; underground stems 3-4 cm long. Bulb depressed globose or ovoid, 10-15 × 10-30 mm, prolonged in a collar, up to $4 \mathrm{~cm}$ long, cataphylls dark-brown, apex acute. Leaves at anthesis1-4, green, plicate, narrowly linear, 6-11 $\times 0.04-0.1$ $\mathrm{cm}$. Flowering stems $7-11 \mathrm{~cm}$, unbranched or furcated at apex. Cauline leaf linear-ensiform, $2.5-3.5 \times 0.2-0.3 \mathrm{~cm}$, base involving the stem. Spathes1-2 per branch, green, herbaceous, bivalved, two-flowered, 14-21 × 1.5-2.5 mm, peduncles $1-3 \mathrm{~cm}$ long. Outer valve $10-14 \mathrm{~mm}$ long, the inner 15-21 mm long, convolute, both with membranous edges. Pedicel filiform, up to $24 \mathrm{~mm}$ long. Flower bluish-white or pallid-blue, radially symmetrical, $14-22 \mathrm{~mm}$ in diameter, at base yellow, surrounded by blue stripes, sometimes absent. Tepals whorls sharply similar in shape and color, spreading, proximally yellow, after with scarce blue stripes, rare absent; outer tepals elliptic to oblanceolate, 7$11 \times 3-5 \mathrm{~mm}$, apex slightly acute to obtuse; inner tepals elliptic, 7-11 $\times 3-5 \mathrm{~mm}$, at apex slightly acute. Filaments free, yellowish, linear and wider at base, 0.7-1.5 mm long; anthers linear, twisted at dehiscence, 2.5-3 mm long; pollen yellow. Ovary obovate, $3-4 \times 1.5 \mathrm{~mm}$. Style yellowish or white, 5-7 mm long; style branches 2-3 mm; stigma truncate, whitish or bluish. Capsule oblong, 7-10 $\times 4-5 \mathrm{~mm}$. Seeds oblong to obconical, ca. 1-1.5 mm long, angled, reddishbrown, epidermis minutely foveolate.

Material examined: ARGENTINA. Corrientes, Bonpland, November 1930, C. Hicken s.n. (SI21725!). San Tomé, Garruchos "cercanías de Garruchos", 10 October 2006, G. Roitman s.n. (BAA 25701!). Monte Caseros, La Pelota, 20 March 1950, E. G. Nicora 5336 (SI!); La Pelota, Bañado del Timbó, 2 November 1950, E. G. Nicora 5629 (SI!); Est. La Pelota, 29 April 1952, E. G. Nicora 6204 (SI!). Entre Rios: Dep. Federación: Salto Grande, laderas pedregosas del río Uruguay, N. Troncoso et al. s.n. (SI 27196!). Misiones: Apóstoles, San José, August 1978, A.L. Cabrera \& N.S. Troncoso 29307 (SI!). BRAZIL. Rio Grande do Sul: Santo Antonio das Missões "locality of Itaroquem, on stony grasslands", $28^{\circ} 37^{\prime} 44.92$ "S$55^{\circ} 18^{\prime} 37.93$ 'W, 9 November 2013, L.P. Deble \& M.I. Paz-Deble 14491 (SI!).

Geographic distribution and habitat: Calydorea minima occurs in northwest Rio Grande do Sul State, Brazil, and eastern Entre 
Rios, northeast Corrientes and southern Misiones, Argentina. The citation from Paraguay made by Roitman \& Castillo (2007) results in a mistake since the voucher $A$. Krapovickas y $C$. L. Cristobal 13429 (CTES!) is currently determined as $C$. approximata $\mathrm{R}$. C. Foster. The extent of occurrence of $C$. minima is estimated smaller than $10,000 \mathrm{~km}^{2}$, and the area of occupancy less than $500 \mathrm{~km}^{2}$. The specimens grow on stony grasslands or grasslands with shallow soils, developed on volcanic rocks.

Ecology, size of populations and natural history: Calydorea minima is one of the most rare species of the genus. The populations occurs exclusively on rock places and the bulbs usually developed in cliffs of the rocks. Specimens flourish between September-November, and can flourish sporadically in other months, mainly after the rain. The flowers open only few hours in one day, in the early morning and wither at midday. C. minima is sympatric with others Iridaceae, as Cypella hauthalii subsp. opalina Ravenna, C. ravenniana Deble \& F. S. Alves, Herbertia sp. and species of Sisyrinchium.

Conservation: The geographic distribution of Calydorea minima is smaller than $10,000 \mathrm{~km}^{2}$, and the area of occupancy is smaller than 500 $\mathrm{km}^{2}$. The populations are fragmented, and composed by few individuals. The reduced number of populations and individual known result in direct threat to this species. According to the IUCN Red List assessment protocol (IUCN 2014) this species can be assigned to the Endangered category (EN, B1, B2b(iii), c(ii)), due to the extent of occurrence, area of occupancy, specific habitat, and anthropic threats observed.

Taxonomic relationships: Calydorea minima is closely related to $C$. alba and $C$. luteola, but can be immediately distinguished by its reduced habit and small floral organs. Furthermore, the tepals shortly fused at base, result in a perigone nearly campanulate in shape. This feature is not observed in others species of Calydorea.
Observations: In the original description of Calydorea minima (Roitman \& Castillo, 2007), two collections were designated as type and the name is not validly published according to article 37.1 of the ICBN (2006). Later, Deble (2011) validated the description and diagnosis of this species.

6. Calydorea riograndensis Deble, Bonplandia (Corrientes) 20: 36. 2011. Typus: BRAZIL. Rio Grande do Sul State: Dom Pedrito "Tacuarembozinho, Sítio Santo Antônio, geófita, entre rochas, no campo hidrófilo, fl. lilases, base vinácea”, 3051'54"S $54^{\circ} 35^{\prime} 47^{\prime}$ 'W, fl. and fr., 16 October 2009, L.P. Deble \& A.S. de Oliveira-Deble 10984 (CTES!). (Figs. 1F, 2)

Description: Plant up to $10-18 \mathrm{~cm}$ high above the soil; underground stems 3-4 cm long. Bulb ovoid, 14-20 × 9-11 mm, prolonged in a collar, up to $4 \mathrm{~cm}$ long, cataphylls dark-brown, apex acute. Leaves at anthesis 4-8, green, plicate, linear, 6-12 $\times 0.06-0.2 \mathrm{~cm}$. Flowering stems 8 $17 \mathrm{~cm}$, furcated at apex. Cauline leaf linearensiform, $2.5-3.5 \times 0.2-0.3 \mathrm{~cm}$, base involving the stem. Spathes 1-2 per branch, green, herbaceous, bivalved, two-flowered, 19-27 × 2$2.5 \mathrm{~mm}$, peduncles $1-1.5 \mathrm{~cm}$ long. Outer valve 13-21 mm long, the inner 19-27 mm long, convolute, both with membranous edges. Pedicel filiform, up to $28 \mathrm{~mm}$ long. Flower violet-blue, sky-blue or pallid-blue, radially symmetrical, $18-25 \mathrm{~mm}$ in diameter, at base yellow, surrounded by violet-blue stripes. Tepals whorls sharply similar in shape and color, spreading, proximally yellow, after with violetblue stripes; outer tepals elliptic to oblanceolate, 11-17 × 4-6 mm, apex slightly acute to obtuse; inner tepals elliptic, $8-13 \times 3-5 \mathrm{~mm}$, at apex slightly acute. Filaments free, yellowish, linear and wider at base, 2-2.6 mm long; anthers linear, twisted at dehiscence, 4-4.5 mm long; pollen yellow. Ovary obovate, $2.3-3 \times 1.2-1.6 \mathrm{~mm}$. Style yellowish, 6.5-7.5 mm long; style branches 2.5-3.3 mm; stigma shortly emarginated, violet. 


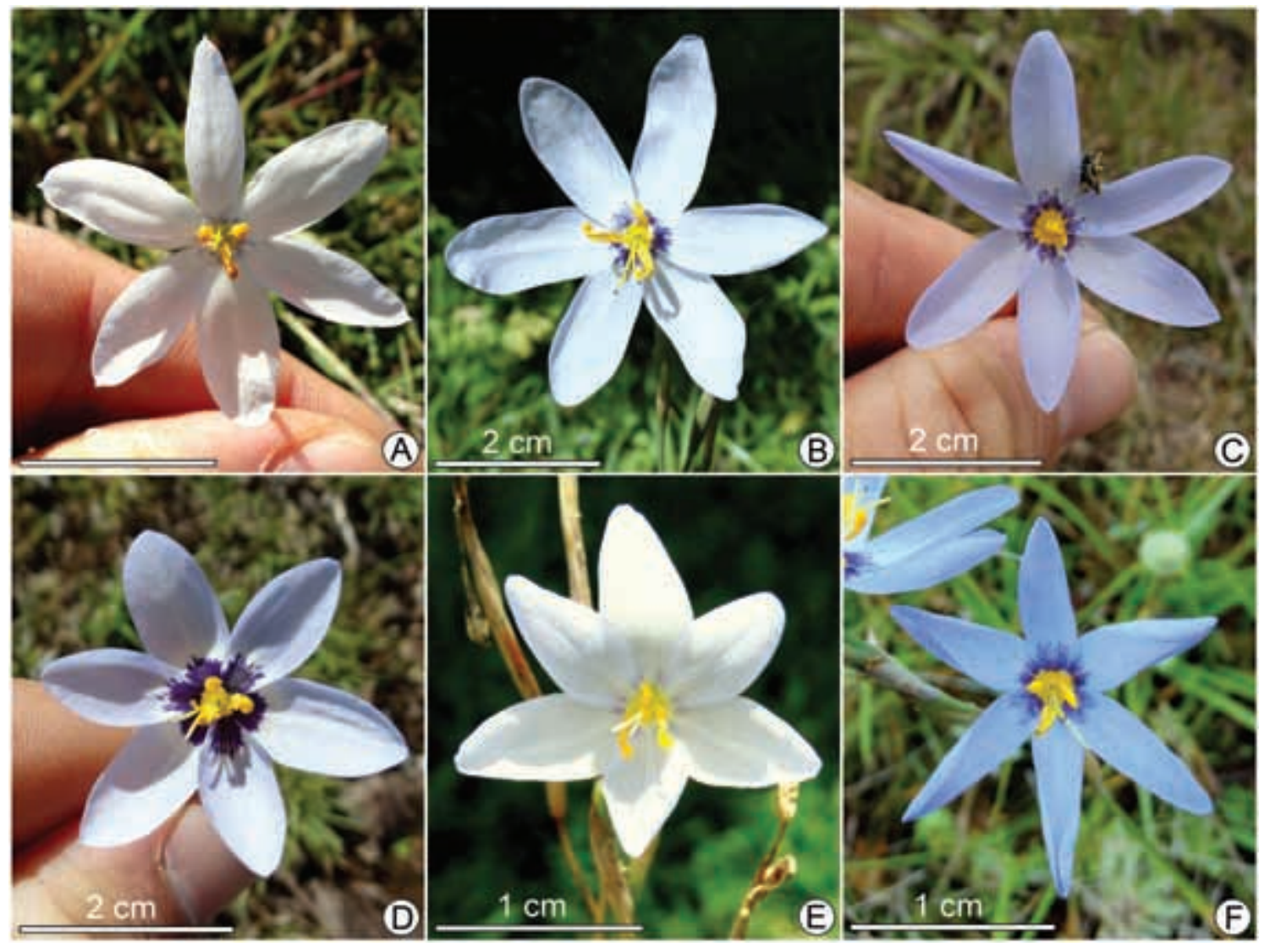

FIGURE 1: Flowers of the species of Calydorea azurea group, frontal view. A - Calydorea alba. B - Calydorea azurea. C - Calydorea charruana. D - Calydorea luteola. E - Calydorea minima. F - Calydorea riograndensis. 


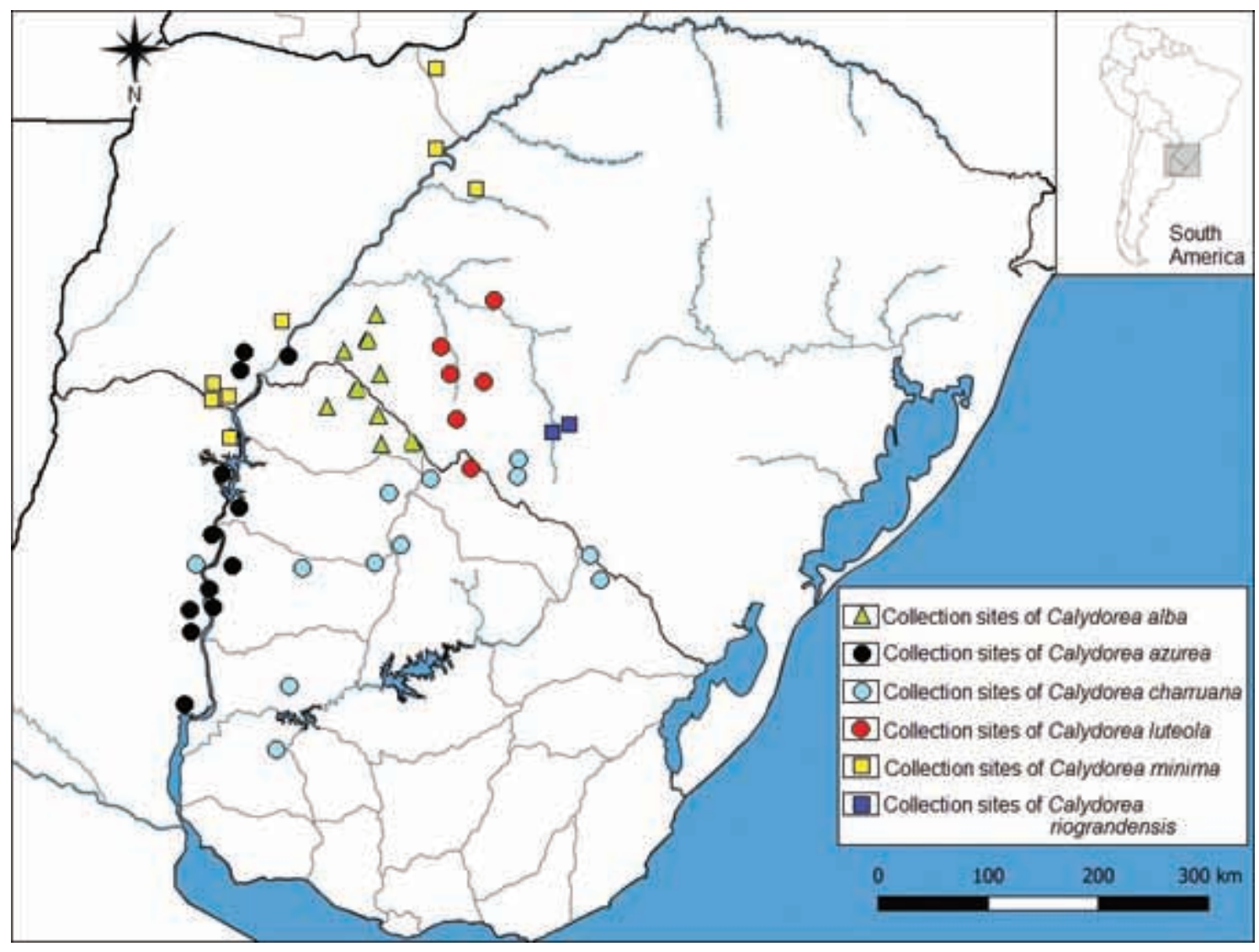

FIGURE 2: Map of geographic distribution of the species of Calydorea azurea group. 
Capsule oblong, 6-9 $\times$ 4-5 mm. Seeds oblong to obconical, ca. 0.9-1.5 mm long, angled, reddishbrown, epidermis smooth, with grooves.

Material examined: BRAZIL. Rio Grande do Sul: Dom Pedrito "Tacuarembozinho, Sítio Santo Antônio, geófita, entre rochas, no campo hidrófilo, fl. lilases, base vinácea", $30^{\circ} 51^{\prime} 54^{\prime \prime} \mathrm{S} 54^{\circ} 35^{\prime} 47^{\prime \prime} \mathrm{W}$, fl. and fr., 16 October 2009, L.P. Deble \& A.S. de Oliveira-Deble 10984 (CTES!); "Tacuarembozinho, Sítio Santo Antônio", 30'51'54"S and 54³5'47'W, fl. and fr., 2 November 2010, L.P. Deble \& A.S. de Oliveira-Deble11435 (CTES!); "área próximo a inundação da barragem do Tacuarembó, rochas e campo hidrófilo", 16 October 2009, L.P. Deble \& A.S. de Oliveira-Deble11078 (CTES!).

Geographic distribution and habitat: Calydorea riograndensis is narrowly endemic in central-southeastern Rio Grande do Sul State, Brazil, in the north of the municipality of Dom Pedrito, in the basin of Tacuarembó River, in an extent of occurrence estimated smaller than $1,000 \mathrm{~km}^{2}$, and an area of occupancy less than $100 \mathrm{~km}^{2}$. The specimens grow on stony grasslands or grasslands with shallow soils to deep, often wet, and with few capacity of drainage, developed on vulcanoclastic rocks of the Tacuarembó geological plateau (see Sommer et al., 2011). This species is sympatric with others Iridaceae, e.g., Cypella pusilla (Link \& Otto) Jackson, Cypella herbertii (Herbert) Herbert, Herbertia darwinii Roitman \& A. Castillo, Herbertia lahue (Molina) Goldblatt, Herbertia amoena Griseb., Kelissa brasiliensis (Baker) Ravenna and Sysirinchium spp.

Ecology, size of populations and natural history: Calydorea riograndensis is one of the most rare and threatened species of the genus, due its reduced extent of occurrence and few places where was registered. According our field observation, this species occur on native grasslands associated with small rivers and streams, often among rocks, and few individuals compose the populations. Specimens flourish between September-November, producing reduced number of fruits and seeds, and can flourish sporadically in others months, mainly after the rain. The flowers open only few hours in one day, in the early morning and wither at midday. During our field activities was observed species of bee (Meliponinae) hovering or nectaring at flowers.

Conservation: Calydorea riograndensis was placed in the status of Endangered by Deble (2011, p. 38); however, this status should be revised since the two vouchers mentioned for Quaraí municipality and the collection from Santana do Livramento municipality were misidentified under $C$. riograndensis (see observation below). The geographic distribution of Calydorea riograndensis is smaller than $1,000 \mathrm{~km}^{2}$, and the area of occupancy is smaller than $100 \mathrm{~km}^{2}$. The populations are severally fragmented, and composed by few individuals. The extent of occurrence of $C$. riograndensis has been used by man, mainly for cattle, and more recently also for mineral extraction. One of the known populations was devastated by the inundation of the Dam Tacuarembó. The increase of mining, silviculture and agriculture result in direct threat to the species. According to the IUCN Red List assessment protocol (IUCN 2014) this species can be assigned to the Critically endangered category (CR, B2ab (iii), c (ii)), due to the extent of occurrence, area of occupancy, specific habitat, and anthropic threats observed.

Taxonomic relationships: Calydorea riograndensis is closely related to $C$. luteola, but can be distinguished by its reduced size of flowers, narrowed tepals and seeds with smooth epidermis and with few longitudinal grooves. Furthermore, both species are geographically isolated, since $C$. riograndensis occurs on Tacuarembó River Basin, while C. luteola spreads in north of Rivera Department, Uruguay, and in southwest Rio Grande do Sul, usually on valleys and lower grasslands.

Observation: Deble (2011) mentioned in the protologue of $C$. riograndensis the paratypes Deble et al. 12483 (CTES!), Deble et al. 12484 (CTES!) and Deble et al. 11485 (CTES!), the 
first-one from Santana do Livramento municipality and the others from Quaraí municipality. These materials are currently determined as C. luteola (Klatt) Baker (Deble et al. 12483) and C. minuana Deble \& F.S. Alves (Deble et al. 12484 and 11485).

Table 1. Morphologic attributes to distinguish the species of Calydorea azurea group

\begin{tabular}{|c|c|c|c|c|c|c|}
\hline Species/character & C. $a l b a$ & C. azurea & C. charruana & C. luteola & C. minima & C. riograndensis \\
\hline $\operatorname{High}(\mathrm{cm})$ & $20-25$ & $20-40$ & $15-35$ & $15-25$ & $8-15$ & $10-18$ \\
\hline $\begin{array}{l}\text { Flower diameter } \\
(\mathrm{mm})\end{array}$ & $25-40$ & $44-56$ & $30-52$ & $24-35$ & $14-22$ & $18-25$ \\
\hline $\begin{array}{l}\text { Outer tepal shape and } \\
\text { length }(\mathrm{mm})\end{array}$ & $\begin{array}{l}\text { oblong or } \\
\text { oblanceolate, } \\
16-20 \times 5-8\end{array}$ & $\begin{array}{l}\begin{array}{l}\text { oblong or } \\
\text { obovate- } \\
\text { oblong } 21 \quad-30 \\
\times 8-11\end{array} \\
\end{array}$ & $\begin{array}{l}\text { oblong or } \\
\text { obovate- } \\
\text { oblong 17-26 } \\
\times 8-11\end{array}$ & $\begin{array}{l}\text { elliptic to } \\
\text { broadly } \\
\text { elliptic } 12- \\
16 \times 5-9\end{array}$ & $\begin{array}{l}\text { elliptic or } \\
\text { oblanceolate, } \\
7-11 \times 3-5\end{array}$ & $\begin{array}{l}\text { elliptic to } \\
\text { oblanceolate, } 11- \\
17 \times 4-6\end{array}$ \\
\hline $\begin{array}{l}\text { Inner tepal shape and } \\
\text { length (mm) }\end{array}$ & $\begin{array}{l}\text { oblong or } \\
\text { oblanceolate } \\
14-19 \times 4.5- \\
7.5\end{array}$ & $\begin{array}{l}\text { obovate- } \\
\text { oblong, } \\
\text { elliptic or } \\
\text { obovate } 18-28 \\
\times 8-11\end{array}$ & $\begin{array}{l}\text { oblong or } \\
\text { elliptic } 16-24 \\
\times 8-10\end{array}$ & $\begin{array}{l}\text { elliptic to } \\
\text { broadly } \\
\text { elliptic } 11- \\
15 \times 5-8\end{array}$ & $\begin{array}{l}\text { elliptic } 7-11 \\
\times 3-5\end{array}$ & $\begin{array}{l}\text { elliptic, } 8-13 \quad \times \\
3-5\end{array}$ \\
\hline Filaments (mm) & $2-3$ & $2-3$ & $2.5-3$ & $2-3$ & $0.7-1.5$ & $2-2.6$ \\
\hline Anthers (mm) & $4-5$ & $5-6$ & $4-5$ & $4-5$ & $2.5-3$ & $4-4.5$ \\
\hline Style & $8-10$ & $8-10$ & $8-10$ & $7-10$ & $5-7$ & $6.5-7.5$ \\
\hline Style branches $(\mathrm{mm})$ & free for 3-5 & free for $2.5-4$ & connate & $\begin{array}{l}\text { free for } 2.5- \\
3.5\end{array}$ & free for $2-3$ & free for $2.5-3.3$ \\
\hline $\begin{array}{l}\text { Stigmatic region } \\
\text { shape }(\mathrm{mm})\end{array}$ & obtuse & $\begin{array}{l}\text { obtuse or } \\
\text { truncate }\end{array}$ & truncate & $\begin{array}{l}\text { shortly } \\
\text { emarginated }\end{array}$ & truncate & $\begin{array}{l}\text { shortly } \\
\text { emarginated }\end{array}$ \\
\hline
\end{tabular}

\section{Acknowledgments}

We are indebted to Andrés González, Facultad de Agronomía, Universidad de la República, Uruguay, for updates on the geographic range of Calydorea charruana and C. luteola in Uruguay, and Mónica Ponce, Instituto Darwinion, by the additional vouchers of Calydorea minima in Entre Ríos (Argentina). Our gratitude also goes to curators and employees of the herbaria visited during the elaboration of this work.

\section{REFERENCES}

AZPIROZ, A. B.; ISACCH, J. P.; DIAS, R. A.; DI GIACOMO, A. S.; FONTANA, C. S.; PALAREA, C. M. Ecology and conservation of grassland birds in southeastern South America: a review. Journal of Field Ornithology, v. 83, n. 3, p. 217-246. 2012.

BAKER, J. G. On Chlamydostylus a new genus of Iridaceae from tropical America and its allies. Journal of Botany British and Foreign, v. 14, p. 184-188. 1876.
BAKER, J. G. Systema Iridacearum. Journal of Linnean Society, Botany, v. 16, p. 61-180. 1877. h t t p://dx.doi.org/10.1111/j.10958339.1877.tb00172.x

BAKER, J. G. Handbook of the Irideae. London, George Bells \& Sons, 1892. 248 pp.

http://dx.doi.org/10.5962/bhl.title.15431

BARKER, C. World Checklist of Iridaceae. Facilitated by the Royal Botanic Gardens, Kew. Available from: http://apps.kew.org/wcsp/ (accessed 12 March 2018)

BEENTJE, H. The Kew Plant Glossary: an illustrated dictionary of plant terms. Royal Botanic Gardens, Kew, 2010. 160 pp.

CHAUVEAU, O.; EGGERS, L.; SOUZA-CHIES, T. T.; NADOT, S. Oil-producing flowers within the Iridoideae (Iridaceae): evolutionary trends in the flowers of the New World genera. Annals of Botany London, v. 110, p. 713-729. 2012. http://dx.doi.org/10.1093/aob/mcs134

DEBLE, L. P. Taxonomic novelties in Calydorea (Iridaceae: Tigridieae). Bonplandia, Corrientes, v. 20, n. 1, p. 35-39. 2011.

DEBLE, L. P.; RODRIGUEZ, J. B.; DEBLE, A. S. 
de O.; FILIPINI, T. G. de L. Taxonomic Novelties in Calydorea Herbert (Iridaceae: Tigridieae) II. Balduinia, Santa Maria, v. 40, p. 1-8. 2013. http://dx.doi.org/ 10.5902/23581980

DEBLE, L. P.; ALVES, F. da S.; DEBLE, A. S. de O. Calydorea minuana, a new species of Iridaceae from Río de La Plata Grasslands, South America. Phytotaxa (Online), v. 253, p. 81-89. 2016.

EGGERS, L. Calydorea in Flora do Brasil $2020 \mathrm{em}$ construção. Jardim Botânico do Rio de Janeiro. Available online: <http:// floradobrasil.jbrj.gov.br/reflora/floradobrasil/ FB8040 >. Accessed: 16 May 2018.

GOLDBLATT, P.; MANNING, J. C. The Iris Family. Natural History and Classification. Portland: Timber Press. 2008. 240pp.

HERBERT, W. Calydorea. Edward's Botanical register, v. 29, p. 85. 1843.

IBGE, Instituto Brasileiro de Geografia e Estatística. Mapa da vegetação do Brasil e Mapa de Biomas do Brasil, 2004. Available online: http:// www.ibge.gov.br/ Accessed: 2 May 2018.

IUCN Standards and Petitions Subcommittee. 2014. Guidelines for Using IUCN RedList Categories and Criteria. Version 11. Prepared by the Standards and Petitions Subcommittee. Cambridge U.K. Available from: http:// www.iucnredlist.org/documents /RedListGuidelines. pdf.

MCNEILL, J.; BARRIE, F. R.; BURDET, H. M.; DEMOULIN, V.; HAWKSWORTH, D. L.; MARHOLD, K.; NICOLSON, D. H.; PRADO, J.; SILVA, P. C.; SKOG, J. E.; WIERSEMA, J. H.; TURLAND, N. J. (eds.). 2006. ICBN International Code of Botanical nomenclature (Viena Code). Regnum Veg. 146pp.

KLATT, F.W. Specimen e familia Iridacearum. Linnaea 31: 533-570. 1862.

KLATT, F. W. Irideae. In: C. F. P. von Martius \& A. G.Eichler (eds), Flora Brasiliensis v. 3, t. 1, p. 510-548. 1871. C. Wolf et fil. \& S. Minsinger, Munich.

KLATT, F.W. Ergantzungen und berichtgungen zu Baker's Systema Iridacearum. Abhandlungen der Naturforschenden Gesellschaft zu Halle, v.15, p. 44-404. 1882.

OLSON, D. M.; DINERSTEIN, E.; WIKRAMANAYAKE, E. D.; BUERGESS, N. D.; POWELL, G. V. N.; UNDERWOOK, E. C.;
D'AMICO, J. A.; ITOUA, I.; STRAND, H. E.; MORRISON, J. C.; LOUCKS, C. J.; ALLNUTT, T. F.; RICKETTS, T. H.; KURA, Y.; LAMOREUX, J. F.; WETTENGEL, W. W.; HEDAO, P.; KASSEM, K. R. Terrestrial ecoregions of the world: a new map of life on Earth. BioScience, v. 51, p. 933-938. 2001.

RAVENNA, P. New species in the genus Calydorea (Iridaceae) I. Onira Botanical Leaflets, v. 9, n. 3, p. 23-24. 2003.

RAVENNA, P. New species of South American bulbous Iridaceae. Onira Botanical Leaflets, v. 10, n. 13, p. 39-45. 2005.

RAVENNA, P. A survey in the genus Cypella and its allies (Iridaceae). Onira Botanical Leaflets, v. 12, n. 1, p. 1-11. 2009.

ROITMAN, G.; CASTILLO, J. A. Calydorea alba (Iridaceae, Tigridieae) a new species from Uruguay. Boletín de la Sociedade Argentina de Botánica, v. 40, n. 3-4, p. 311-312. 2005.

ROITMAN, G.; CASTILLO, J. A. Calydorea minima (Iridaceae: Tigridieae), a new species from South America. Boletín de la Sociedade Argentina de Botánica, v. 42, n. 3-4, p. 321-323. 2007.

SOMMER, C. A.; de LIMA, E. F.; PIEROSAN, R.; MACHADO, A. Reoignimbritos e ignimbritos de alto grau do vulcanismo Acampamento Velho, RS: origem e temperatura de formação. Revista Brasileira de Geociências, v. 41, n. 3, p. 420435. 2011.

SORIANO, A.; LEÓN, R. J. C.; SALA, O. E.; LAVADO, R. S.; DEREGIBUS, V.A.; CAHUEPÉ, O.; SCAGLIA, A.; VELAZQUEZ, C. A.; LEMCOFF, J. H. Río de la Plata grasslands. In: COUPLAND, R.T. (Ed.) Ecosystems of the World. Natural Grasslands. Introduction and Western Hemisphere. Elsevier, Amsterdam, p. 367-407. 1992.

THIERS, B. Index Herbariorum: A global directory of public herbaria and associated staff. New York Botanical Garden's Virtual Herbarium. Available online: http://sweetgum.nybg.org/ih/. Accessed: 14 February 2018.

URBAN, I. Biographisce Skizzen, I. Friedrich Sellow, 1789-1831. Botanische Jahrbücher für Systematik, Pflanzengeschichte und Pflanzengeographie. Leipzig, v. 17, p. 178198. 1893. 